\title{
Structural capacity assessment of machine-building enterprises and associations
}

\author{
Elena Kuznetsova ${ }^{1, *}$, Anastasia Akulova ${ }^{1}$, and Marina Zhuravskaya ${ }^{2}$ \\ ${ }^{1}$ Mechanics and Machine Building Institute, Ural Federal University, Russia \\ ${ }^{2}$ Ural State University of Railway Transport, Yekaterinburg, Russia
}

\begin{abstract}
The use of "green" logistics technologies for the Russian transport system is designed to reduce the damage to the environment, it becomes a competitiveness factor, and gives the service "quality criterion". Among many areas of "green" logistics, the authors considered the development of piggyback transport and the organization of utilization system as the most promising and priority for the Russian transport market. The advantages and key challenges in organizing piggyback in Russia are revealed. To overcome the current limitations, it is suggested to enable the conditions, that should be taken into account when calculating the tariffs for transportation and take into account the impact of the mode of transport on the ecology. The authors discuss the direct and indirect positive effects of as part of reverse logistics for the transport market of the Russian Federation. The actual task is to form the utilization market as an independent branch of activity. The article analyzes the domestic and foreign experience in addressing these issues, formulates the problems and challenges for further research.
\end{abstract}

\section{Introduction}

Economic globalization and scientific and technological progress in the $\mathrm{XX}$ century led to the formation of powerful transport networks, to increasing of the types of rolling-stock and to strengthening the role of transport in the world economy. Transportation, as one of the main components of industrial and social infrastructure, allows to ensure freight traffic between the objects of economic activities and spatial mobility of the population. For example, following the results of 2013 passenger traffic grew by $12.8 \%$, freight turnover by $7 \%$ compared with 2010 , reflecting a significant increase of the industry in recent years [1].

Despite it, at the moment before the transport complex of the country there is a number of strategically important tasks. One of them is the integration of domestic transport in the world transport system that contributes to the development of national economy and achieving the main goal: increasing the competitiveness of domestic goods and services in the global market. Achieving this goal is impossible as long as the Russian transport and logistics companies won't be guided by the global trend of "sustainable development".

According to researches «Towards Sustainable Logistics» [2] about 59\% of the surveyed firms believe that "green" technologies of transportation their products will be the deciding factor when choosing a partner. According to a study QSHE Global (5400 survey respondents) [3], we can conclude about the relation to introduction of environmental technologies in the business processes of modern companies:
- $61 \%$ - cares about the environment;

- $67 \%$ - choose partners, oriented on "green logistics";

- $82 \%$ - use the principles of "green" logistics to improve the image;

$-30 \%$ - are willing to pay extra for environmental technologies.

Therefore, improving the competitiveness of the transport system of the country and the quality of transport services is not possible without the introduction of the principles of "green" logistics.

At such statement of a question there is a need to review and analyze the various "green" technologies in transport and transport-technological systems; development of various methods and approaches to measure the effectiveness of these technologies; determining the area of responsibility of the state in creating and ensuring market mechanisms contributing introduction of environmentally friendly technologies; formation of matrix of "green" technologies to provide various spheres of transport. These questions, and many others, require additional researches and discussions. Among a set of the directions of "green logistics", the authors considered the most promising for transport of the Ural region the development of piggyback transport and the organization of utilization system.

\section{2 "Green Logistics" as a way of development}

In general sense, logistics is considered as the science of planning, management and control of the movement of

Corresponding author: eltcha@mail.ru 
material, informational, and financial resources. Therefore, we can say that modern global problems associated with deterioration of environment, resource depletion, social problems are connected with imperfect approach to the organization of logistical processes, for this reason there is need a methodological framework which would allow eliminating harmful ecological consequences of logistic operations.

In 1987 for the first time were told words about the need to go by means of "sustainable development", meaning that, support and meet the needs of the present without compromising the ability of future generations to meet their own needs [4].

In foreign sources in recent years there are many works devoted to "green logistics" as part of "sustainable development", there are several points of view on its place in the economic activity, are offered a variety of approaches to supply chain management at the junction with the environment. For example, De Burgos and Lorente [5] are talking about improving the environment as an operational objective and the supply chain is secondary. Baumann et al. [6] give special attention to the development of green products in a narrow framework of the logistics chain. Zisdisin and Siferd [7] are conducted a review of environmental procurements. Abukhader and Jönson [8] analyzed the interaction and interrelationship of the environment and logistics Kleindorfer et al. [9] conducted a review and assessment of the publications in the field of "management of sustainable operations", but they consider issues related to supply chain. Srivastava [10] describes Reverse logistics. Elkington [11] argues that the integration of heavily interrelated economic, environmental and social aspects of sustainability gives "triple bottom line."

Russian authors [12] propose to understand the term "green logistics" as "... the scientific and practical activities aimed at optimization and efficient management of direct and reverse material streams and related to them (information, financial, waste streams, hazardous emissions, of different natural resources and energy) in order to minimize the negative impact on the environment".

In the context of the concept of "green logistics" is offered not only to reduce the burden on the environment by reducing emissions and install treatment plants, various bans and increased taxation, is assumed a new approach to the organization of production, through the introduction of innovative technologies, the use of the latest energy-saving efficient equipment, the transition to a resource efficient approaches exploitation of technics and organization of production, rational use of resources and the withdrawal of outdated machines and equipment out of service, using the principles of reverse logistics. The role of the last one in reducing the impact on the environment is that it "closes" the logistic chain, and allows you to manage product life cycle from raw material extraction to disposal. However, given the rising cost of raw materials and energy, the transition to energy-efficient production principle promises to be cost-effective, not only due to the effect of the public good, but also from improving the competitiveness of the product, owing to decreasing of production costs and marketing efforts.

To date, the most striking example of the introduction of "green" technologies belongs to transport and logistics company DHL, which started the service Go Green. Under this program, the customer pays on 3\% higher of the tariff, as compensation for the damage caused to the ecology, the money is invested in environmental protection measures around the world.

German Deutsche Bahn for the first time in the European rail branch offered a way of transportation goods, completely eliminating carbon dioxide emissions. Within the project EcoPlus the company receives electricity for their electric locomotives from renewable energy sources by attracting additional funds from the companies whose goods are transported, for example, concern AUDI [13].

Among domestic transport companies adhere to the sustainable development strategy of JSC "Russian Railways", which implements a number of innovative projects accompanied by resource-saving and environmentally friendly technologies: is replaced the railroad tracks, put into operation new diesel locomotives and electric locomotives with increased energy efficiency.

Thus, speaking about road transport, it is possible to formulate two major problems whose solution involves the use of environmental technologies: 1) reduction of the share of harmful emissions into the atmosphere; 2) minimizing resource and energy consumption.

\section{Piggyback as an element of eco- oriented logistics}

At present, within the framework of the environmental program of JSC "Russian Railways" conducts marketing research attractiveness of piggyback technology in the Russian market, which are more environmentally friendly combined transports "car-rail".

Piggyback first were organized in Central Europe, combining the advantages of road and rail transport, and it is three-stage combined shipping. Initially, goods are transported by road train to railway station, then the vehicle (trailer/semi-trailer) are loaded on a flat-car and transported to the terminal station, from this station the descended from the platform truck delivers the goods to a final consumer. A distinctive feature of these transportations is exactly transportation of road train on a flat-car the main part of the route.

Road transport is one of the most powerful air pollutants, and, unfortunately, in recent years this trend has changed slightly. In Table 1 presents data on air pollution by different sources, from this table you can see, that the road transport emissions account for about $40 \%$ of the total, while the share of road transport is only $4.9 \%$ of the total freight turnover of the country. Rail transport for comparison, with a market share of $43.2 \%$ in freight turnover, has a small proportion of emissions [14]. 
Table 1. Percentage of emissions by types of source in 20082013 (data for Russian Federation).

\begin{tabular}{|c|c|c|c|c|c|c|}
\hline Year & 2008 & 2009 & 2010 & 2011 & 2012 & 2013 \\
\hline $\begin{array}{l}\text { Total } \\
\text { emissions, } \\
1000 * \text { tonne } \\
\text { s / year, of } \\
\text { which: }\end{array}$ & 33691 & 32560 & 32220 & 32488 & 32309 & $\begin{array}{l}3187 \\
1\end{array}$ \\
\hline $\begin{array}{l}\text {-from } \\
\text { stationary } \\
\text { sources, } \\
1000 * \text { tons / } \\
\text { year }\end{array}$ & 20103 & 19021 & 19116 & 19162 & 19630 & $\begin{array}{l}1844 \\
7\end{array}$ \\
\hline $\begin{array}{l}\% \text { from } \\
\text { stationary } \\
\text { sources }\end{array}$ & 59.67 & 58.42 & 59.33 & 58.98 & 60.76 & $\begin{array}{l}57.8 \\
8\end{array}$ \\
\hline $\begin{array}{l}\text {-from road } \\
\text { transport, } \\
1000 * \text { tons / } \\
\text { year }\end{array}$ & 13588 & 13539 & 13105 & 13325 & 12679 & $\begin{array}{l}1342 \\
4\end{array}$ \\
\hline $\begin{array}{l}\% \text { of road } \\
\text { transport }\end{array}$ & 40.33 & 41.58 & 40.67 & 41.02 & 39.24 & $\begin{array}{l}42.1 \\
2 \\
\end{array}$ \\
\hline $\begin{array}{l}\text { - from } \\
\text { railway } \\
\text { transport, } \\
1000^{*} \text { tonne } \\
\text { s / year }\end{array}$ & $\mathrm{n} / \mathrm{d}$ & $\mathrm{n} / \mathrm{d}$ & $\mathrm{n} / \mathrm{d}$ & 140 & 159.5 & $\begin{array}{l}192 . \\
5\end{array}$ \\
\hline $\begin{array}{l}\% \text { of rail } \\
\text { transport }\end{array}$ & - & - & - & 0.004 & 0.005 & $\begin{array}{l}0.00 \\
6 \\
\end{array}$ \\
\hline
\end{tabular}

Currently in Europe, successfully are implemented piggyback both within the country and international transportations, mostly they are intermodal technology. Organizers of the Piggyback route "Gallarate (Italy) Maze (Belgium)" talk about reducing the transportation costs by $15-17 \%$, decreasing of emissions by $20 \%$ and of fuel consumption by $2.5 \mathrm{mln}$. liters. Company COMBIDEM organizing piggyback in France, talk about reducing transportation costs by $10 \%$ and reducing emissions by $70-75 \%$.

Analysis of opinions of researchers and scientists in the field piggyback [15 -19], allowed to form a table with the advantages of this type of transport organization and barriers to its development (Table 2). The main difficulties in the organization of piggyback in Russia are connected with the need to create the appropriate infrastructure and regulatory framework.

Table 2. Advantages and limitations of the organization piggybank in Russia.

\begin{tabular}{|c|c|}
\hline Advantages & Limitations \\
\hline $\begin{array}{l}\text { - reducing of harmful } \\
\text { emissions; } \\
\text { - economic efficiency of } \\
\text { transportation for distances } \\
\text { over } 1000 \mathrm{~km} \text {; } \\
\text { - unloading of highways of } \\
\text { megalopolises; } \\
\text { - decrease in load of a } \\
\text { roadbed; } \\
\text { - the accelerated passing of } \\
\text { customs points. }\end{array}$ & $\begin{array}{l}\text { - need of creation of a specialized } \\
\text { rolling stock; } \\
\text { - absence of the working models for } \\
\text { these type of transportations } \\
\text { organized on "long" routes (in } \\
\text { Russia an average distance is } 3-4 \\
\text { thousand km, in Europe } 700-800 \\
\mathrm{~km} \text { ); } \\
\text { - absence of standard and legal base } \\
\text { for maintenance of transportations; } \\
\text { - absence of tariff base for } \\
\text { piggyback }\end{array}$ \\
\hline
\end{tabular}

To overcome the current limitations it is necessary to create the stimulating conditions in the market of transport services. The system of fines and encouragement at calculation of tariffs for types of transport is offered [20]. This method takes into account the impact of the mode of transport on the environment in the form of increasing or decreasing coefficients for the fixed and variable costs. Using of these coefficients allows to displace the point of change of scenario of transport services (CP-change point) [21], which is calculated as the ratio of the difference of fixed costs by mode of transport to the difference variable costs by mode of transport, closer to the origin of coordinates, which reduces the area of the effective operation of road transport (value F2, V2) and increases it for the railway transport (F1, V1) (Figure 1). Such a scheme of tariffs directly contributes to the development of piggyback.

However, despite the significant shortcomings of road transport (high share of emissions, low security) refuse completely from road transport it won't turn out as only they allow you to organize the delivery of "door to door", and for some areas it is still the only available type of transport. Therefore, it is necessary to develop an organizational chart of eco-friendly solutions for road transport at every stage of its life cycle.

\section{Recycling as part of resource-saving tecnologies}

The second direction of development of "green" logistic, obvious for development of the Russian transport market, is solving the problems of utilization as part of "reverse logistics". For a transport complex of Russia, and especially for its automobile constituent, management of a stage of life cycle "recession" is especially actual as more than a half of vehicle fleet of the country has the obsolescence and wear. The balanced development of branch is possible only at continuous improvement of structure of its fixed assets therefore their growth and updating is the most important condition of providing "sustainable development" of branch.

Today the analysis of age structure of fleet of vehicles (Table 3 ) shows that the considerable part of transport units is operated outside standard service life, another, also considerable, part comes nearer to this term. As a result, ecological indicators, indicators of safety and economic efficiency of work of transport are significantly worsening.

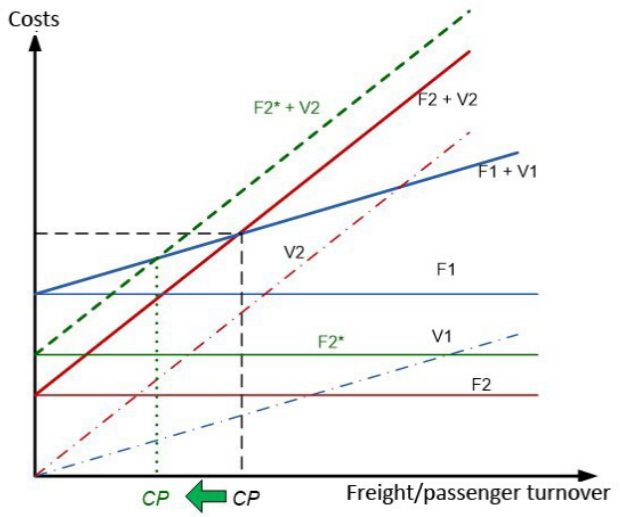

a) 


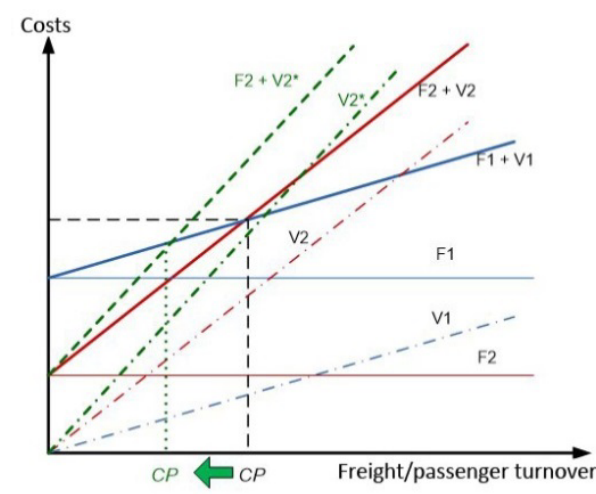

b)

Fig. 1. Displacement of point of change scenario of transport services (CP) with the introduction of green fines for a) fixed costs b) variable costs of vehicles.

Table 3. The age structure of the fleet of vehicles at the end of 2013 [14].

\begin{tabular}{|l|l|l|l|}
\hline \multicolumn{4}{|l|}{ The age structure of the fleet of vehicles, \% } \\
\hline Type of vehicle & to 5 years & $5-10$ years & $\begin{array}{l}\text { More than } \\
10 \text { years }\end{array}$ \\
\hline Trucks & 21.8 & 20.1 & 58.1 \\
\hline Buses & 27.0 & 27.7 & 45.3 \\
\hline Cars & 30.7 & 24.6 & 44.7 \\
\hline
\end{tabular}

Many researchers in the framework of sustainable development, have engaged by issues of "reverse logistics" which describes the movement of material streams from a final point of consumption of a product prior to new life cycle.

Creating a system of utilization of vehicles will have an integrated beneficial effect. First, decrease in harmful emissions and costs, increase of safety of transportations and energy efficiency, thanks to stimulation of updating of vehicle fleet. The first experiment conducted in Russia in 2010-2012 on utilization of cars gave a double budgetary effect, and growth of a value added was about 150 billion rub at expenses in 30 billion rubles Second, resource conservation by recycling materials, so, according to Western scholars, recycling of medium car weighing about 1 ton saves $3,300 \mathrm{~kg}$ of material resources, reduces energy consumption per 56,000 MJ, reduces emissions on $1945 \mathrm{~kg}$. Third, the reduction of environmental pollution by obsolete cars as well as reducing space required for their storage.

In European countries, the utilization market has long refers to an independent branch of activity. According to the European Automobile Manufacturers Association, the profit from recycling one car in the EU is around 340 euros, and with deduction of payment of land, premises, equipment depreciation - 300. In Germany, European leader in the number of cars (43.4 million units. 81 million inhabitants), is utilized an annual average of 450 th. cars, and in some years, when is started recycling programs, similar to our 2010-2011., 2 million old cars. Another example of the successful formation of the utilization branch is the Netherlands. Coefficient of utilization of vehicles in the Netherlands to 2011 amounted to $96.2 \%$ and it is the highest in the world, and most importantly, that the financing of this system every year requires fewer additional resources. Here, from the buyer is taken recycling tax of 45 euros, which is included in the price of a new car.

Unlike foreign countries, the domestic branch of utilization is in a rudimentary stage therefore it is necessary to develop the market mechanisms stimulating participation in questions of utilization not only the private sector and car makers, but also other subjects of the transport complex of Russian Federation.

The directions of "green" logistics considered in article aren't only options on the way to a sustainable development of transport system of the country. The separate attention is deserved by a question of formation of algorithm of a choice of these or those "green" approaches depending on appointment and a stage of life cycle of transport unit.

The authors see the need to further examine in more detail the methods of management the final stage of the life cycle, as every year the relevance of this issue is only growing. In particular, it is planned to create an organization chart of utilization market and its optimization in transporttechnological system.

\section{References}

1. State report "On the state and Environmental Protection of the Russian Federation in 2013". http://www.mnr.gov.ru/upload/iblock/6c7/gosdoklad eco.pdf

2. Dr. Christof, E. Ehrhart, Delivering Tomorrow: Towards Sustainable Logistics (2012). http:// www.delivering-tomorrow.com

3. K. Alexandrova, The RZD Partner International, 3(39), 38-39 (2014)

4. Report of the World Commission on Environment and Development: Our Common Future.

5. De Burgos, J. Jiménez, Céspedes, J.J. Lorente, International Journal of Operations \& Production Management, 21(12), 1553-1572 (2001)

6. H. Baumann, F. Boons, A. Bragd, Journal of Cleaner Production, 10(5), 409-425 (2002)

7. G.A. Zsidisin, S.P. Siferd, European Journal of Purchasing \& Supply Management, 7(1), 61-73 (2001)

8. S.M. Abukhader, G. Jönson, International Journal of Logistics: Research and Applications, 7(2), 137-149 (2004)

9. P.R. Kleindorfer, K. Singhal, L.N. Van Wassenhove, Production and Operations Management, 14(4), 482-492 (2005)

10. S.K. Srivastava, International Journal of Management Reviews, 9(1), 53-80 (2007)

11. J. Elkington, Cannibals with Forks: The Triple Bottom Line of 21th Century Business (Capstone, Oxford, 1997)

12. A. Tambovtsev, T. Tambovtseva, Management and sustainable development, 2/2011 (29) 
13. A.A. Kizim, D.A. Kabertaj, Bulletin of the Southern Federal District, 8 (2012)

14. Transport of Russia" Informational and statistical Bulletin.http://www.mintrans.ru/upload/iblock/5cd/s tat_2014.pdf

15. М.A. Zhuravskaja, I.O. Макаrenko, Transport of the Urals, 3(38), 74-79 (2013)

16. V.V. Baginova, D.V. Kuzmin, Modern problems of the transport complex of Russia, 4 (2013)

17. K.V. Holopov, Russian foreign economic journal, 9 (2011)

18. A.G. Kirillova, Rail transport, 2 (2011)

19. D. Kyzmin, A. Belyh, Modern problems of the transport complex of Russia, 4 (2013)

20. M.A. Zhuravskaja, Journal of USURT, 1(25), 38-48 (2015)

21. M.A. Zhuravskaja, A.A. Kazakov, P.A. Parsurova, Transport of the Urals, 4, 50-53 (2012) 